\title{
Supporting Muslim Students Through Culturally Relevant, Responsive, and Sustaining Pedagogies
}

\author{
Nisreen Alameddine \\ Brock University, Canada \\ na17hc@brocku.ca \\ https://orcid.org/0000-0002-7393-6665
}

\section{Article Info}

Received: February 26, 2021

Revised: June 10, 2021

Accepted: June 19, 2021

doi https://doi.org/10.29173/css20

This is an Open Access article distributed under the terms of the CC BY 4.0 International license.

(https://creativecommons.org/licenses/by/4.0)
ABSTRACT

In this article, I discuss a conceptual framework for supporting Muslim students using Culturally Relevant, Responsive, and Sustaining Pedagogies informed by a Collaborative Inquiry approach. The impact of 9/11 and its consequences on Muslim students' temporal and social contexts calls for a critical stance that questions teachers' assumptions regarding Muslim students. I examine Critical Pedagogy as the theoretical underpinnings for employing Culturally Relevant, Responsive, and Sustaining Pedagogies with the intent of underscoring the significance of incorporating these pedagogies to build upon teachers' capacities in honouring the voices of their Muslim students and fostering spaces for these voices to speak up. I explore how teachers can engage in Culturally Relevant, Responsive, and Sustaining Pedagogies through Collaborative Inquiry to meet the needs of Muslim students in ways that acknowledges their narratives and support them in navigating their social and academic environments.

\section{KEYWORDS}

Muslims, responsive, relevant, sustaining, critical pedagogy 


\section{Introduction}

Studies have explored how students' attributes and behaviours might impact teachers' views about their students' competencies (de Boer et al., 2010; Ready \& Wright, 2011; Timmermans et al., 2016). However, teachers' perceptions and pedagogical approaches to support students from diverse backgrounds remain an area for further research. There is a need to explore pedagogical strategies that respond to classroom diversity based on discussions around biases. Biases operate both implicitly and explicitly, as individuals might struggle to acknowledge and navigate their partialities (Ehrlinger et al., 2005; Niyozov \& Niyozov, 2010; Pronin, 2006; van den Bergh et al., 2010). As a result, rigid notions about students can have serious implications on teacherstudent relationships as well as student well-being, particularly for those from diverse backgrounds (Peterson et al., 2016; Rubie-Davies, 2010). Teachers' predefined perceptions of Muslim students may be influenced by biased views about Muslims (Guo, 2015; Niyozov \& Niyozov, 2010; Zine, 2001). These biases can foster relational hierarchies and reinforce conflicting ideas of inclusion and diversity that impact Muslim students' living experiences (Ali-Khan, 2014; Collet, 2007; Zine, 2000).

In the aftermath of the tragic events of 9/11, a prejudicial discourse on Muslims was reinforced (Elmasry \& el-Nawawy, 2020; Kanji, 2018; Poynting \& Perry, 2007). This discourse, however, dates back several years to ongoing "Orientalism" that places Muslims in a position of subordinate status relative to the West (Said, 1978, 2003a). In that respect, I critically reflect, as a Muslim researcher/teacher, on the significance of supporting Muslim students and amplifying their voices by first considering the current social contexts of Muslims in Canada. Then, I explore a theoretical overview of Culturally Relevant (Ladson-Billings, 1995b), Responsive (Gay, 2002; 2010a), and Sustaining Pedagogies (Paris, 2012) grounded in Critical Pedagogy and facilitated through a Collaborative Inquiry approach (Borko, 2004; Nelson et al., 2008; Putnam \& Borko, 2000). I argue that this framework presents an opportunity for educators to continuously reassess their practices and mobilize Culturally Relevant, Responsive, and Sustaining strategies for reaching out to their Muslim students.

\section{My Positionality as a Muslim Researcher/ Teacher}

Being Muslim Arab teacher allows me to engage meaningfully with students and families with similar backgrounds and worldviews. Some of the exchanges I had with teachers made me realize that teachers' cultural expectations and fixed beliefs shape common understandings about marginalized groups (Britzman, 2000; Rizvi \& Lingard, 2006). These shared perceptions create inaccurate representations that affect marginalized students' experiences and outcomes (Cummins, 2011). Several scholars argue that dismantling oppression is not contingent on solitary critical thinking since biases interfere with validating other groups' power and influence the interpretation of various bodies of knowledge (Britzman, 1998; Ellsworth, 2001; Kumashiro, 2000; North, 2008). Therefore, I am aware that many teachers' Anglo mainstream positionalities dictate, to a certain extent, their normative views and the differential power relations that govern their circles of existence, in similar manners that my experiences as a Muslim women researcher and teacher shape my interpretations and understanding.

I am also aware of my location as a settler on the traditional lands of the Mississaugas of the Credit, part of the Anishinaabe Nation, Haudenosaunee, Attawandaron, and the Métis. I am proclaiming the right for my voice as a Muslim to be recognized, when a reconciliation process demands an acknowledgement of Canada's settler history and an affirmation of Indigenous knowledge and rights (Truth and Reconciliation Commission of Canada, 2015). The dilemma of negotiating my position in various networks necessitates a self-reflexive stance (Britzman, 2000). This stance underscores my moral and ethical obligations and demands 
my acknowledgment confessing that the subjugation to settler-colonial agenda contributes to perpetuating social injustice falling upon Indigenous peoples (Tuck \& Yang, 2012).

\section{Muslims in Times of Turmoil}

The ongoing repercussions of $9 / 11$ reduced all Muslims into a single racialized entity that portrayed them as the "enemy" (Ali-Khan, 2014; Kumar, 2010; Said, 2003b). Such portrayal intensified Muslims' exclusion process and allowed Islamophobia to thrive (Bazian, 2018; Giroux, 2002; Hanniman, 2008; Khalema, \& Wannas-Jones, 2003). According to Toronto Police Services (2018), Religion accounted for 51\% of all hate crime incidents reported in Toronto in 2018; Jewish and Muslim communities were the two most targeted, respectively (Toronto Police Services, 2018). The report also indicates that "The Muslim community was the most frequently victimized group for assault occurrences" (Toronto Police Services, 2018, p. 2). Recently, tragic massacres in Quebec (Von Hlatky \& Ibrahim, 2017) and New Zealand (Stewart, 2019) claimed Muslim lives in their worship places. The depiction of Muslims as the enemy reflects the portrayal of the "Orient" as fundamentally different from the West and, more importantly, the tradition of the "clash of civilizations' narrativizations that continues to dominate identity politics (Arat-Koç, 2006; Bazian, 2018; Said, 2003a, 2003b). Accordingly, 9/11, the events that followed, and media portrayals of those events reinforce biases and discriminatory views against Muslim communities (Saeed, 2007; Singh, 2016; Schmuck et al., 2018). These views continue to impact Muslims' ability to negotiate their values within a westernized lens (Ali, 2014; Dragonas, 2004; Leeman \& Saharso, 2013; Niyozov \& Pluim, 2009; Younis \& Hassan, 2019).

The portrayal of Muslims as the enemy perpetuates apprehension that could prevent teachers from reaching out to their Muslim students and recognizing their diverse narratives (Guo, 2015). This apprehension is often accompanied by inadequate preparation for addressing religious and cultural diversity in K-12 classrooms (Guo et al., 2009; Guo, 2015; Kayaalp, 2019). Accordingly, Eurocentric ideologies drive the design of curriculum, pedagogy, delivery, and evaluation methods frequently used by teachers (Kayaalp, 2019; Shultz, 2011). Teachers may base their interactions with Muslim students on inaccurate understandings of Islam leaving Muslim students' voices unheard and delegitimized in class (Guo, 2015; Shultz, 2011). These factors, among others, emphasize the deficit model that views difference as a shortcoming of the student or their family and community (Abdi, 1997; Kayaalp, 2019). Clycq et al. (2014) suggested that the deficit model might lead to "problematization of the home environment" (p. 808), which could further alienate Muslim families and their children and undermine their agency in affirming their histories. Biesta (2007) noted that "...the idea of education as a treatment or intervention that is a causal means to bring about particular, preestablished ends - is not appropriate for the field of education" (p. 10). Thus, I question whether traditional educational frameworks recognize the many ways in which students from diverse cultural and religious backgrounds claim their stories and draw on their backgrounds to navigate their academic and social school experiences.

\section{Othering Muslim Students' Voices}

Muslim students can experience injustice on two levels; they may experience preconceived beliefs that permeate the classroom walls and negatively affect teacher-student relationships (Guo, 2015), while simultaneously experiencing an educational system that distances their voices and pathologizes their lived experiences under the notion of inclusion. Consequently, students might react in different ways to delegitimizing practices (Kumashiro, 2000; McDonough \& Hoodfar, 2005; Niyozov \& Pluim, 2009). Some Muslim children and youth could relinquish aspects of their cultural/ religious narratives to fit in (Kayaalp, 2014). Other Muslim students who desire to be part of the dominant collective narrative might overcompensate 
to prove themselves worthy of an environment that restricts their agency in acknowledging their cultural and religious backgrounds (Hua, 2018; Zhao et al., 2005). Alternately, some Muslim students could resort to resistive and defiant measures that signal their attempt to legitimize their backgrounds (Collet, 2007; Zine, 2000). Nevertheless, as Kumashiro (2000) noted "...despite the apparent differences between those students who 'succeed' and those who 'fail' or simply fail to distinguish themselves, all experience oppression" (p. 27).

\section{Multicultural Education and the Perpetuation of Otherness}

All students carry sets of worldviews constituting their narratives (García, 1991; van Kessel, 2020; van Kessel \& Saleh, 2020); Muslim students are no exception. The idea behind multicultural education is to recognize and include these diverse perspectives and the variety of ways in which different groups experience their world (Banks \& Banks, 2010). Yet, the educational system often compounds Muslim students' marginalization by not explicitly addressing the power structures that exclude their narratives and views them as a subordinate group that needs to assimilate (Amjad, 2018; Guo, 2012). The term inclusion suggests developing, providing, and revising policies and services to those systematically/pedagogically excluded. Inclusion, however, is not an unbiased term, especially in communities where dominant groups' authority influences educational goals (Cummins, 1997; Parker-Jenkins et al., 2017). So, educational structures should critically examine whether students from diverse backgrounds are being excluded through systemic processes rooted in misguided notions of multiculturalism and inclusion (Reitz et al., 2009; Ozturgut, 2011; Sleeter \& Stillman, 2005). Kumashiro (2001, p. 5) stated that reliance on inclusion as the sole mechanism to acknowledge diversity is not enough because: (1) there is no possible way to account for all differences; and (2) labelling the Other accentuates the boundaries of exclusionary criteria. Educators might be constrained by boundaries that dictate the interpretations of inclusion and diversity in a society governed by inequitable power relations (Ainscow et al, 2016). It is, therefore, imperative that educators examine the power dynamics implicit and explicit in their roles and examine whether their classrooms demonstrate pedagogical strategies that privilege/Other students, thus maintaining exclusionary boundaries (2001, p. 5).

Considering some of the dehumanizing experiences that harm Muslim students, the role of multicultural education becomes ever so crucial in disrupting the process of marginalization by viewing diversity as an asset that brings about social cohesion between different groups in a society (Banks et al., 2001; McGee \& Banks, 1995). Gibson (1984, p. 95) examined five multicultural education approaches: (1) Education of the Culturally Different, (2) Education about Cultural Differences or Cultural Understanding, (3) Education for Cultural Pluralism, (4) Bicultural Education, and (5) Multicultural Education as the Normal Human Experience. Whereas the first four approaches can accentuate the process of labelling students from diverse backgrounds, the fifth offers an opportunity to emphasize and broaden multicultural competencies that are transferable between different cultures (Gibson, 1984). Doucet and Adair (2013) further explored multicultural approaches by examining two educational strategies that underscore the others who are profoundly unlike the dominant group: (1) the colour-blind approach that focuses on what is common among people; and (2) praising diversity, which highlights celebrating special days/ months, events and foods that depict diverse ethnicities.

These different interpretations of multicultural education become a part of the dominant culture norms, thereby serving mainstream Canadian identity and citizenship notions (El-Sherif \& Sinke, 2018; Waters \& Leblanc, 2005). However, in the process of validating a cohesive national identity, educational systems create a dissonance or clash that threatens the relationship between teachers and their Muslim students and alienates those students from their surroundings (Amjad, 2018; Sahli et al., 2009). When their implicit and explicit biases guide teachers, they might perceive diversity as a source of strain or additional workload to accommodate their students from diverse backgrounds (Castagno, 2008; Civitillo et al., 2021; Gay, 2010b; 
Tatar \& Horenczyk, 2003; Gutentag et al., 2018).).Therefore, multicultural approaches must acknowledge the existence of the various hierarchies that govern power relations and the socialization processes in classrooms and beyond (Ozturgut, 2011; Sleeter \& Stillman, 2005). Socialization is especially critical for Muslim youth who might be struggling to proclaim their voices given the political and social climates that define views of Muslims in general (Ali, 2014; Ali-Khan, 2014; Amjad, 2018; Khawaja, 2016; Sirin \& Balsano, 2007).

Arguably, there is a need to reframe success and failure discourses in more profound ways than just rejecting the deficit model. Reframing requires mechanisms that allow educators to address their practices, as well as an environment in which stakeholders' interests and boundaries are clearly defined, rather than being ambiguous and open to alternate interpretations that situate Muslim students at a disadvantage. Teachers should provide classroom experiences that sustain their student's diverse backgrounds and holistically engage them in their learning journey without jeopardizing their experiences' legitimacy (Cummins, 1997; Paris \& Alim, 2017; Zine, 2002). Importantly, humanizing classroom interactions would allow teachers and students to co-construct success pathways that redefine students' agency (Paris, 2012). No doubt that some educators engage in these approaches and actively practice commitment and care towards their Muslim students (Niyozov \& Pluim, 2009). Recent reforms, such as the publication of the "Islamic Heritage Month Resource Guide" by the Toronto District School Board (TDSB, 2017), reflect Muslims' emergent awareness as partners within Canadian society's fabric. This awareness, however, needs to be translated into proactive measures that center Muslim students' positions as part of a community that holds the burden of the aftermath of $9 / 11$, at the heart of critical classroom experiences. These proactive measures suggest addressing the infrastructural and pedagogical barriers that place students from diverse backgrounds at a disadvantage and limit their ability to establish their presence in their surroundings (Kohli et al., 2017).

\section{Critical Pedagogy: A Transformative Process}

Drawing from Freire's Pedagogy of the Oppressed (1972), the conceptualization of Otherness suggests subjugating the oppressed through the banking concept of education that strengthen oppressive dominant structures. In this context, Giroux and McLaren (1987) believed that schools could disrupt the dominance of "consensual practices" that polarize people into either "us" or "them" (in Darder et al., 2017, p. 11; Giroux \& Giroux, 2005; Mclaren; 2002). Muslim students bring diverse perspectives and histories to classrooms, making them more than mere spectators who live on the margins; instead, they can make a difference in shifting power dynamics and disrupting hegemonic ideologies. In respect, Bowers and Appfel-Marglin (2005) explore the challenging tasks of addressing the dominant educational discourse and prompt educators to evaluate their beliefs and assumptions in classrooms. How do these views impact what topics are discussed in class in relation to Muslims? How do educators respond to their Muslim students? In what ways do teachers exclude/ include under the notion of a democratic way of thinking? McLaren (1992) brings on the complexity of these questions by stating that "reading about racism and oppression is not the same thing as living as their victim" (p. 8). Thus, Critical Pedagogy, as conceptualized by Freire (1972), Giroux and McLaren (1987; 1992), gives students and teachers the chance to engage in a dialect that defies and shifts dominant narratives surrounding Muslims. When educators approach their classes as an experience of investigation and discovery" (Said, in Viswanathan, 2001, p. 280), they engage in a critical disposition that questions assumptions about individuals from diverse cultural/ geographical boundaries (Rizvi \& Lingard, 2006). 


\section{Is Critical Pedagogy Enough for A Transformation?}

No one perspective contains a holistic approach towards addressing the experiences of Muslim students in Canadian public schools. In its attempt to normalize the other, Critical Pedagogy failed to alter the concept of normal (Ellsworth, 1989); it still maintained a centralized characterization of Otherness without attempting to distinguish the backdrops of different subjugating experiences (Darder et al., 2017; Weiler, 1991). This centralization in Critical Pedagogy undermines its attempt to differentiate Muslim students' voices. In a powerful statement, Roman (in Nieto, 1999) states that "To have knowledge of another culture does not mean to be able to repeat one or two words in a student's language, nor is it to celebrate an activity or sing a song related to their culture." As educators, we must critically examine how classrooms are perpetuating injustices by discrediting Muslim students' personal experiences considering the discourse surrounding Muslims. We must question whether we are humanizing Muslim students' stories and histories (Saleh, 2021) through pedagogical approaches that maintain and authenticate their stories and sentiments (Paris, 2011).

Failure to distinguish these backdrops could lead to a disengagement from differing bodies of knowledge and the power these entail. This disengagement could contribute to a status quo that renders experiences of Muslim students invisible. Gur-Ze'ev (2005) noted that Critical Pedagogy is becoming "decreasingly relevant to the victims it is committed to emancipate" (p. 10). Efforts to create a universal change that fits every context are inconceivable (Biesta, 1998). Imposing the alternatives would ultimately bind us to the oppressors as our histories and prejudices shape our future visions. Educators who consider assimilation and resilience the only alternatives for creating change that includes Muslim students' voices fail to consider the temporal and social contexts in which Muslims live. Without exposing and challenging context complexities and power relations, Critical Pedagogy alone cannot change the relationship between teachers and their Muslim students. As educators, we must reconstruct knowledge in a way that admits to the multiple perspectives that this knowledge entails. We must also acknowledge our biases and fears if we are to grow into this new knowledge and incorporate it into school interactions that impact Muslim students. A self-reflection that questions the power we derive from our different perspectives is necessary to admit our prejudicial beliefs and apprehensions. This introspection remains an area of self-discovery as we engage in Culturally Relevant, Responsive, and Sustaining Pedagogies in our classrooms.

\section{Towards a framework for Culturally Relevant, Responsive, and Sustaining Pedagogies}

Culturally Relevant, Responsive, and Sustaining Pedagogies offer other channels through which emancipatory education could capitalize on Muslim students' backgrounds and perspectives and provide them with the opportunity to validate their identities. Culturally Relevant Pedagogy (Gloria Ladson-Billings, 1995a, b) asserts the right of culturally and linguistically diverse students to achieve high academic achievement while upholding their cultural identities. Similarly, Culturally Responsive Pedagogy (Gay, 2002; 2010 a) facilitates classroom practices that embrace but also empower diverse forms of knowledge instead of allowing them to exist on the margins.

As such, Culturally Relevant and Responsive Pedagogy (CRRP) (Kugler \& West-Burns, 2010) is based on Gloria Ladson-Billings' (1995a, b) Culturally Relevant Pedagogy and Geneva Gay's (2002; 2010a) Culturally Responsive Pedagogy to promotes equity and social justice in Ontario's education systems and their teacher professional development mission. Paris (2012) further expands on the terms Relevant and Responsive by offering the notion of Culturally Sustaining Pedagogy that requires "...more than responsive of or relevant to the cultural experiences and practices of young people - it requires that they support young people in sustaining the cultural and linguistic competence of their communities while simultaneously offering access to dominant cultural competence" (p. 95). 
Culturally Relevant, Responsive, and Sustaining Pedagogies emphasize the recognition of students' contexts as vital contributors to their well-being (Doucet, 2017; Kugler \& West-Burns, 2010; Paris, 2017). When Muslim students are situated in an environment that does not recognize their distinctive narratives, this may lead to a disconnection between their lived experiences and their cultural or religious identity (Zine, 2006, 2006). Moreover, this disconnection is exacerbated when Muslim students feel that their experiences are not authenticated by the normative scripts that define them (Amjad, 2018; Zine, 2003, 2012). Such alienation might even prompt students to detach from their home-culture and school environment if they sense the power dynamics that situate them at a disadvantage (Fillmore, 2000). Ultimately, Culturally Relevant, Responsive, and Sustaining Pedagogies offers the chance to disrupt dehumanizing views about Muslims by empowering educators to engage in a process that brings about a sense of solidarity and acknowledgment of the diverse ways of being in and experiencing the world.

\section{What is Culturally Relevant and Responsive Pedagogy?}

Culturally Relevant Pedagogy warrants incorporating students' backgrounds within their learning experience beyond focusing on celebratory approaches that exotify the "Other" as subordinate (LadsonBillings, 1995b; 1998). Such approaches take the stance of praising differences to divert attention from the embedded systems that alienate Muslim students. Affirming cultural/religious diversity should be fortified by critical conversations that allow students to voice their perceptions and concerns (Doucet \& Adair, 2013). Accordingly, educators should be aware of the socio/political contexts in which these conversations occur and not be apprehensive about integrating them explicitly into conversations (Ladson-Billings, 2014; Maged, 2014). Socio/political contexts could serve as a vehicle through which students and teachers disengage from a binary mode of thinking and recognize differential power relations patterns (DiAngelo \& Sensoy, 2014). Per se, teachers should recognize that their positionalities impact how students envision their prospects and the worth of their backgrounds (Cummins, 2001).

Geneva Gay $(2002 ;$ 2010a) proposed the notion of Culturally Responsive Pedagogy that employs students' knowledge repertoire as a medium through which teaching-learning occurs. Students' lived experiences and hybrid identities become the premises upon which critical conversations are brought up in class (Gay, 2002). Delpit (2006) points out how being a "model teacher" who conforms to dominant instructional approaches could refute their students' knowledge, which reproduces different delegitimizing perspectives. Similarly, Cummins (2001) reminds us that when educators relay the message that their students' backgrounds are significant, students will sense that their knowledge is valuable and are more likely to use it as a foundation for their knowledge. Teachers should recognize that students come into the class with previously formed understandings, which shape their school experiences. Educators do not give their students voices; instead, students already have voices, and teachers should provide them with a place and means to speak up. Through CRRP, classrooms would become places where students showcase their knowledge and different identities, but importantly, practice their agency in claiming their histories and lived experiences. As George Dei (2006) advises, "inclusion is not bringing people into what already exists; it is making a new space, a better space for everyone"

\section{Extending CRRP into Culturally Sustaining Pedagogy}

Paris $(2012$; 2017) drew on CRRP by adding the concept of sustaining pedagogies for multicultural competence that acknowledges student's distinct backgrounds and fosters them alongside the prevailing cultural and linguistic proficiencies. As such, Culturally Sustaining Pedagogy strives to establish schooling as part of positive transformation that nurtures linguistic, literate, and cultural pluralism. (Paris \& Alim, 2017, p. 1). Interestingly, Delpit (1998) recognized that for students to acquire dominant competencies, they must 
establish codes of participation, autonomy, and governance, which, in turn, make it possible for them to participate in cultures of power and declare their narratives. Hence, in a manner, sustaining pedagogies acknowledges that curriculum comes with "unwritten codes" that have an impact on students' ability to access equitable opportunities in their learning environment (Dei, 2016). The curriculum, itself, becomes a tool by which dominant power reproduces itself (Dei, 2016). To redistribute power equitably, we need to validate students' cultural repertoire and foster it beside dominant multicultural competencies to ensure that students from diverse backgrounds access equitable learning experiences (Lee \& Walsh in Paris \& Alim, 2017). Among these experiences are storytelling, critical dialogues, and teachings that openly address issues of equity and justice and allow for "fluid understandings of culture" (Ladson-Billings, 2014, p. 74).

The fluidity of this understanding paves the way for a plurality of competencies that are reflective of Muslim students' voices and perspectives. In relation, a significant aspect of Culturally Sustaining Pedagogies is the involvement of families and communities, as these provide a medium for the transmission of intergenerational cultural practices (Lee, 2017, p. 166) These practices are part of Muslim students' cultural and religious competencies that bridge the diversity in their backgrounds to the learning environment. However, such a pedagogical asset can only be developed if educators are willing to foster these connections and admit to their relevance.

Ultimately, a framework of Culturally Relevant, Responsive, and Sustaining Pedagogies works towards breaking barriers to Muslim students' active engagement in their learning experiences and acknowledging that the school climate reflects a broader societal climate that still grapples with the echoes of 9/11. In effect, this struggle shapes the authenticity of reaching out to Muslim students and is likely to undermine Muslim students' narratives and their ability to successfully navigate school experiences. Developing Culturally Relevant, Responsive and Sustaining Pedagogies facilitates Muslim students' empowerment by legitimizing their discourses; it enables school systems to recognize the differential pathways of students' learning and adjust the learning environment accordingly to maintain those pathways. In such a way, recognition holds the essence of individualization of the learning process, and the acknowledgment of Muslim students' temporal and social locations, given that some might be still contending with misunderstandings about who they are and what they can do following the 9/11 event (Lebowitz, 2016). These misunderstandings might not be communicated explicitly; nevertheless, they negatively impact Muslim students, as biases and discrimination hinder equitable representation in education. Ultimately, recognition admits that "human relationships are at the heart of schooling" (Cummins et al., 2005, p. 42) that honours students' identities and embraces their backgrounds as sites of empowerment and cultural pluralism rather than disintegration (Paris, 2012).

Critically, educators should reflect on the notion of obligation to care for those in need, thereby perpetuating a charity model, rather than the authentic belief that Muslim students have an equal right to be represented and their voices heard. Such distinction needs to be perceptible because it underscores the societal structural inequalities that are not explicitly addressed. Cummins (1997) notes how policies and reforms have partially failed to address inequitable educational opportunities because of the impact of powerful ideologies that create our mindsets and dictates our perceptions of the others (p. 650). We can set policies and reforms that inform educators how to implement certain strategies, but education is more than a process of knowledge exchange, it is a process governed by beliefs, ideas, and actions. These beliefs are partially the product of a general socio-political climate that is centuries in the making. Roberts (2015) stated that "every time a teacher steps into a classroom or any other educational environment, he or she carries with him or her an implied set of ethical and political preferences. The teacher's role is not to deny these preferences but to reflect critically on them and to allow the students opportunities to do the same with other ideals" (p. 382). This strain between our preferences and those of our students is essential in our journey to engage in transformative pedagogies 
that legitimizes the narratives of Muslim students. In exploring these tensions, teachers should consider building an inquiry process into Culturally Relevant, Responsive, and Sustaining Pedagogies, which not only provide the space for Muslim student voices, but also gives Muslim students opportunities to maintain their agency in representation.

\section{Culturally, Relevant, Responsive and Sustaining Pedagogies through Collaborative Inquiry}

Collaborative Inquiry (CI) is a channel through which educators can engage in Culturally, Relevant, Responsive, and Sustaining Pedagogies to work towards developing classroom environment that supports diverse perspectives (Delpit, 1998; DeLuca et al., 2015). CI provides educators the opportunity to explore specific areas of their practice, reflect on these practices and beliefs, and formulate new understandings about their theories of pedagogy to design responsive practices that employ their students' competencies (Donohoo, 2013; Lee, 2009). Fostering Culturally, Relevant, Responsive and Sustaining Pedagogies through CI is fundamental for revealing barriers affecting Muslim students' experiences and educational attainment. These systemic and attitudinal barriers invalidate Muslim students' perspectives and hamper their ability to reconcile their various histories and identities with the environment (Ali, 2014; Amjad, 2018; Castagno, 2008; Sahli et al., 2009; Zine, 2006; 2012). By engaging in a critical analysis of their pedagogical discourses, CI serves the purpose of empowering educators to employ Culturally, Relevant, Responsive, and Sustaining Pedagogies and create holistic learning experiences that acknowledge Muslim students' voices.

The approach for engaging in CI is inspired by the "First Nation, Métis and Inuit Focused Collaborative Inquiry (CI)" that was part of the "Listening Stone" Project (Dion, 2016). ${ }^{1}$ The project focused on building successful relations between First Nations, Métis and Inuit communities and schools, as well as delivering educational prospects that support the participation of First Nations, Métis and Inuit communities in a manner that warrants legitimacy of their histories, perspectives, and knowledge (Dion, 2016). As such, CI attends to the temporal locations and historical factors that situate Muslim youth and their families in a disadvantaged position. These factors include facing Islamophobia considering the socio/political variables that delineate Muslims and render their image the adversary. No doubt that 9/11 cast its shadows on Muslim youth's experiences in schools; hence, CI would allow educators to question their assumptions considering Muslims' socio/political narratives and how these narratives impact their relations with their Muslim students.

In that respect, humility should be part of the inquiry process through which teachers admit to their privileged position as part of the dominant group (DiAngelo \& Sensoy, 2014). Humility opens new possibilities of critical thinking and active engagement with students (Lund, 2006). When educators see their role as fostering social justice and equity, they are more likely to create forms of transformative pedagogical practices that reframe their teacher- students' relations and sustain students' identities (Giroux \& McLaren, 1987; Paris, 2012; Zine, 2012). Adopting Culturally, Relevant, Responsive, and Sustaining Pedagogies also necessitate a "culture of professional development" whereby educators are involved in the continued process of building and developing their competencies to support their students (Kugler \& West-Burns, 2010). CI would serve this goal by supporting communities of practice that broadens teachers' capacities to extend the effect of Culturally, Relevant, Responsive, and Sustaining Pedagogies across and beyond school sites through community engagement (Deppeler \& Ainscow, 2016; Nelson et al., 2008). This commitment allows educators to question

\footnotetext{
1 "The Listening Stone Project" in 2014 uncovered findings that included evidence of discomfort experienced by teachers, which is partly driven by insufficient knowledge. The project recommended sharing experiences across districts to maximize opportunities for learning between different communities of practice.
} 
their understandings and privileges, and approach their practices as an opportunity to learn from and with their students (Guo et al., 2009; Sensoy \& DiAngelo, 2014; Tuncel, 2017)

Still, attitudinal barriers might prohibit educators from active engagement in CI. A proactive approach in Culturally, Relevant, Responsive, and Sustaining Pedagogies taps into people's internal belief systems and confronts their mindsets (Brown, 2004). These beliefs are not only influenced by the type of knowledge or practice educators acquire, but their positions also shape them within their local/global socio-political systems (Britzman, 1998; Lin \& Rice, 2008; Van Den Bergh et al., 2010). What remains debatable is whether Culturally, Relevant, Responsive, and Sustaining Pedagogies plays a genuine role in modifying teachers' attitudes towards Muslim students and supporting positive learning experiences that push back against central power structures. Educators need to admit that stifling some voices is sometimes intentional and partly stems from the comfort of common understandings (Kumashiro, 2001). However, Guishard (2009) states that discomfort should be considered "...space to understand and not retreat from social consciousness inquiry" (p. 103).

Though CI could yield discomfort (Ainscow et al., 2016), educators should distinguish between discomfort and safety (Sensoy \& DiAngelo, 2014). Safe environments can be uncomfortable because they expose the power undercurrents that regulate social relationships. One would argue that discomfort is essential because it indicates a conflict between entrenched beliefs and social justice and equity principles. Such discomfort might urge educators to critically question rooted views and foster more inclusive practices that signal a shift in their mindsets (Deppeler \& Ainscow, 2016; Sensoy \& DiAngelo, 2014). Hence, Culturally, Relevant, Responsive, and Sustaining Pedagogies through CI requires schools to become areas that provide safe environments for educators and students to voice their opinions and take risks in developing alternative ways of thinking and acting (Kugler \& West-Burns, 2010).

\section{Conclusions}

Approaches that cultivate Culturally Relevant, Responsive, and Sustaining Pedagogies through CI can uncover power relations in classrooms while transforming teachers' work into pedagogical practices that support Muslim students' academic attainment and legitimize their narratives. Implementing Culturally Relevant, Responsive, and Sustaining Pedagogies through CI centralize the question of "what do our students already know and experience?" to dismantle structures that silences Muslim students and trivializes their discourses; it allows students and teachers to become collaborators in deciphering the otherness, thus, allowing for new forms of knowledge to be created (Solorzano \& Bernal, 2001). These forms of knowledge admit to the lived experiences of Muslim students in the aftermath of $9 / 11$ and affirms their rights in accessing equitable educational opportunities and outcomes while upholding their religious/ cultural backgrounds. DiAngelo and Sensoy $(2014$, p. 9) state: "As instructors, we are embedded in and facilitate complex relations of power in the classroom, and we want to address that power in intentional, strategic, and critical ways." Teachers' approaches to learning about the lived experiences of their Muslim students impacts how these students view their backgrounds and envision their futures. By implementing Relevant, Responsive, and Sustaining Pedagogies through CI, educators can provide safe spaces for their Muslim students to share their narratives and recreate knowledge in ways that frame these narratives as powerful representations of thinking and experiencing the world.

Ideally, education would work towards bringing about social justice and providing an equal standard of living to everyone. Fair and unbiased opportunities in learning help students become proactive and independent within their surroundings. This level of engagement strengthens societal unity and enhances the student's sense of belonging to their community without jeopardizing their religious/cultural background 
(Banks et al., 2001; Gardner \& Toope, 2011). When schools are part of a network that recognizes Muslim students and their experiences, the risk of alienation is reduced. Teachers can build bridges that minimize fear between different groups of society and safe routes of connection and continuity. These bridges can be achieved through pedagogical approaches that honour, respect, cherish, and support students' identities; through pedagogies that are Relevant, Responsive, and Sustaining.

\section{References}

Ainscow, M., Dyson, A., Goldrick, S., \& West, M. (2016). Using collaborative inquiry to foster equity within school systems: opportunities and barriers. School Effectiveness and School Improvement, 27(1), 7-23. https://doi.org/10.1080/09243453.2014.939591

Ali, A. (2014). A threat enfleshed: Muslim college students situate their identities amidst portrayals of Muslim violence and terror. International Journal of Qualitative Studies in Education, 27(10), 12431261. https://doi.org/10.1080/09518398.2013.820860

Abdi, A. A. (1997). Anti-Racism Education: Theory and Practice [Review of Anti-Racism Education: Theory and Practice]. Canadian Journal of Education / Revue Canadienne de L'éducation, 22(4), $472-474$. Canadian Society for the Study of Education. https://doi.org/10.2307/1585805

Ali-Khan, C. (2014). Misinformation and its Discontents: Critical Pedagogy and the Challenges of Islamophobia. In K. Tobin \& A. Shady (Eds.), Transforming Urban Education: Urban Teachers and Students Working Collaboratively (pp. 149-165). SensePublishers. https://doi.org/10.1007/978-946209-563-2_9

Amjad, A. (2018). Muslim students' experiences and perspectives on current teaching practices in Canadian schools. Power and Education, 10(3), 315-332. https://doi.org/10.1177/1757743818790276

Arat-Koç, S. 2006. “Whose Transnationalism? Canada's 'Clash of Cilvilizations' Discourse, and Arab and Muslim Canadians.” In L. Wong and V. Satzewich (Eds.), Transnational Identities and Practices in Canada (pp. 216-240). UBC Press

Banks, J. A., \& Banks, C. A. M. (2010). Multicultural education: issues and perspectives (7th ed.). Wiley.

Banks, J, A., Cookson, P., Gay, G., Hawley, W. D., Irvine, J. J., Nieto, S., ... Stephan, W. G. (2001). Diversity within unity: Essential principles for teaching and learning in a multicultural society. Phi Delta Kappan, 83(3), 196-203. https://doi.org/10.1177/003172170108300309

Bazian, H. (2018). Islamophobia, "clash of civilizations", and forging a post-cold war order. Religions (Basel, Switzerland ), 9(9), \#282, 1-13. https://doi.org/10.3390/re19090282

Biesta, G. (1998). Say you want a revolution...suggestions for the impossible future of critical pedagogy Educational Theory, 48(4), 499-510. https://doi.org/10.1111/j.1741-5446.1998.00499.x

Biesta, G. (2007). Why "what works" won't work: Evidence based practice and the democratic deficit in education. Educational Theory, 57(1), 1-22. https://doi.org/10.1111/j.1741-5446.2006.00241.x

Borko, H. (2004). Professional Development and Teacher Learning: Mapping the Terrain. Educational Researcher, 33(8), 3-15. https://doi.org/10.3102/0013189X033008003

Bowers, C., \& Apffel-Marglin, F. (2005). Rethinking Freire : globalization and the environmental crisis . Lawrence Erlbaum.

Britzman, D. (1998). Lost subjects, contested objects toward a psychoanalytic inquiry of learning. State University of New York Press.

Britzman, D. (2000). Teacher Education in the Confusion of Our Times. Journal of Teacher Education, 51(3), 200-205. https://doi.org/10.1177/0022487100051003007 
Castagno, A. E. (2008). "I don't want to hear that!": Legitimating whiteness through silence in schools. Anthropology \& Education Quarterly, 39, 314-333. https://doi.org/10.1111/j.15481492.2008.00024.x.

Civitillo, S., Juang, L. P., \& Schachner, M. K. (2021). Stressing similarities or ignoring differences? Shedding light into different forms of color-evasive ideology with pre- and in-service teachers. Zeitschrift Für Erziehungswissenschaft, 24(1), 135-153. https://doi.org/10.1007/s11618$\underline{\text { 021-00995-9 }}$

Collet, B. (2007). Islam, national identity and public secondary education: perspectives from the Somali diaspora in Toronto, Canada. Race, Ethnicity and Education, 10(2), 131-153. https://doi.org/10.1080/13613320701330668

Cummins, J. (1997). Cultural and linguistic diversity in education: A mainstream issue? Educational Review (Birmingham), 49(2), 105-114. https://doi.org/10.1080/0013191970490202

Cummins, J. (2001). Negotiating identities: education for empowerment in a diverse society (2nd edition). California Association for Bilingual Education.

Cummins, J., Bismilla, V., Chow, P., Giampapa, F., Cohen, S., Leoni, L., Sandhu, P., \& Sastri, P. (2005). Affirming identity in multilingual classrooms. Educational Leadership, 63(1), 38-.43

Cummins, J. (2011). Identity matters: From evidence-free to evidence-based policies of promoting achievement among students from marginalized social groups. Writing \& Pedagogy, 3(2), 189-216. https://doi.org/10.1558/wap.v3i2.189

Clycq, N., Ward Nouwen, M., \& Vandenbroucke, A. (2014). Meritocracy, deficit thinking and the invisibility of the system: Discourses on educational success and failure. British Educational Research Journal, 40(5), 796-819. https://doi.org/10.1002/berj.3109

Darder, A., Torres, R. D., \& Baltodano, M.P. (2017). The Critical Pedagogy Reader ( ${ }^{\text {rd }}$ ed.). New York: Taylor and Francis.

de Boer, H., Bosker, R., \& van der Werf, M. (2010). Sustainability of Teacher Expectation Bias Effects on Long-Term Student Performance. Journal of Educational Psychology, 102(1), 168-179. https://doi.org/10.1037/a0017289

Dei, G. (2006). Meeting equity fair and square [Keynote address]. Leadership Conference of the Elementary Teachers' Federation of Ontario, Mississauga, Ontario.

Dei, G. (2016). Decolonizing the university: the challenges and possibilities of inclusive education. Socialist Studies/Études Socialistes, 11(1), 23-23.

https://socialiststudies.com/index.php/sss/article/view/24704/19971

Delpit, L. (1988). The Silenced dialogue: Power and pedagogy in educating other people's children. Harvard Educational Review, 58(3), 280-299. https://doi.org/10.17763/haer.58.3.c43481778r528qw4

Delpit, L. (2006). Other people's children: Cultural conflict in the classroom. New Press.

DeLuca, C., Shulha, J., Luhanga, U., Shulha, L. M., Christou, T. M., \& Klinger, D. A. (2015). Collaborative inquiry as a professional learning structure for educators: A scoping review. Professional Development in Education, 41(4), 640-670.

Deppeler, J., \& Ainscow, M. (2016). Using inquiry-based approaches for equitable school improvement. School Effectiveness and School Improvement, 27(1), 1-6. https://doi.org/10.1080/09243453.2015.1026671

DiAngelo, R., \& Sensoy, Ö. (2014). Calling in: Strategies for cultivating humility and critical thinking in antiracism education. Understanding and Dismantling Privilege, 4(2), 190-203.

Dion, S. (2014). Listening stone: Learning from the Ontario Ministry of Education's First Nations, Métis and Inuit focused collaborative inquiry 2013-2014. SD Dion Consulting. 
Dion, S. (2016). The listening stone project year three: Starting points, turning points, learning points: Lessons from the First Nations, Métis and Inuit collaborative inquiry 2015-2016. SD Dion Consulting.

Donohoo, J. (2013). Collaborative inquiry for educators: A facilitator's guide to school improvement. Corwin Press.

Doucet, F. (2017). What does a culturally sustaining learning climate look like?. Theory Into Practice, 56(3), 195-204.

Doucet, F., \& Adair, J. K. (2013). Addressing race and inequity in the classroom. YC Young Children, 68(5), 88-97.

Dragonas, T. (2004). Negotiation of identities: The Muslim minority in Western Thrace. New Perspectives on Turkey, 30(1), 1-24. https://doi:10.1017/S0896634600003897

Ehrlinger, J., Gilovich, T., \& Ross, L. (2005). Peering into the bias blind spot: People's assessments of bias in themselves and others. Personality \& Social Psychology Bulletin, 31(5), 680-692. https://doi.org/10.1177/0146167204271570

Ellsworth, E. (1989). Why doesn't this feel empowering? Working through the repressive myths of critical pedagogy. Harvard Educational Review, 59(3), 297-324.

https://doi.org/10.17763/haer.59.3.058342114k266250

Elmasry, M., \& el-Nawawy, M. (2020). Can a non-Muslim Mass Shooter be a "Terrorist"?: A Comparative Content Analysis of the Las Vegas and Orlando Shootings. Journalism Practice, 14(7), 863-879. https://doi.org/10.1080/17512786.2019.1643766

El-Sherif, L., \& Sinke, M. (2018). "One message, all the time and in every way": Spatial subjectivities and pedagogies of citizenship. Curriculum Inquiry, 48(1), 35-52.

https://doi.org/10.1080/03626784.2017.1409590

Freire, P. (2018). Pedagogy of the oppressed. Bloomsbury Publishing USA. (Original work published in 1968)

Gardner, M. K., \& Toope, D. F. (2011). A Social Justice Perspective on Strengths-Based Approaches: Exploring Educators' Perspectives and Practices. Canadian Journal of Education, 34(3), 86-102.

Gay, G. (2002). Preparing for culturally responsive teaching. Journal of Teacher Education, 53(2), 106-116. https://doi.org/10.1177/0022487102053002003

Gay, G. (2010a). Culturally responsive teaching: theory, research, and practice (2nd ed.). Teachers College.

Gay, G. (2010b). Acting on beliefs in teacher education for cultural diversity. Journal of Teacher Education, 61(1-2), 143-152. https://doi.org/10.1177/0022487109347320

Gibson, M. A. (1984). Approaches to multicultural education in the United States: Some concepts and assumptions. Anthropology \& Education Quarterly, 15(1), 94-120.

https://doi.org/10.1525/aeq.1984.15.1.05x1476t

Giroux, H. (2002). Democracy, freedom, and justice after September 11th: Rethinking the role of educators and the politics of schooling. Teachers College Record (1970), 104(6), 1138-1162.

https://doi.org/10.1111/1467-9620.00199

Giroux, H., \& Giroux, S. (2006). Challenging neoliberalism's new world order: The promise of critical pedagogy. Cultural Studies, Critical Methodologies, 6(1), 21-32.

https://doi.org/10.1177/1532708605282810

Giroux, H, \& McLaren, P. (1987). Teacher education as a counterpublic sphere: Radical pedagogy as a form of cultural politics. Philosophy \& Social Criticism, 12(1), 51-69.

https://doi.org/10.1177/019145378701200103 
Guo, Y. (2012). Diversity in Public Education: Acknowledging Immigrant Parent Knowledge. Canadian Journal of Education, 35(2), 120-140. http://www.jstor.org/stable/canajeducrevucan.35.2.120

Guo, Y. (2015). Pre-Service teachers and Muslim parents: Exploring religious diversity in Canadian public schools. Diaspora, Indigenous and Minority Education, 9(3), 189-204. https://doi.org/10.1080/15595692.2015.1014033

Guo, Y., Arthur, N., \& Lund, D. (2009). Intercultural inquiry with pre-service teachers. Intercultural Education (London, England), 20(6), 565-577. https://doi.org/10.1080/14675980903448619

Gur-Ze'ev, I. (2007). Beyond postmodern feminist critical pedagogy: Toward a diasporic philosophy of counter-education. In Beyond the Modern-Postmodern Struggle in Education, pp. 149-183. Brill Sense.

Guishard, M. (2009). The false paths, the endless labors, the turns now this way and now that: Participatory action research, mutual vulnerability, and the politics of inquiry. The Urban Review, 41(1), 85-105. https://doi.org/10.1007/s11256-008-0096-8

Gutentag, T., Horenczyk, G., \& Tatar, M. (2018). Teachers' approaches toward cultural diversity predict diversity-related burnout and self-Efficacy. Journal of Teacher Education, 69(4), 408-419. https://doi.org/10.1177/0022487117714244

Hanniman, W. (2008). Canadian Muslims, Islamophobia and national security. International Journal of Law, Crime and Justice, 36(4), 271-285. https://doi.org/10.1016/j.ijlcj.2008.08.003

Hua, L. (2018). Slow feeling and quiet being: Women of color teaching in urgent times. New Directions for Teaching and Learning, 2018(153), 77-86. https://doi.org/10.1002/t1.20283

Kanji, A. (2018). Framing Muslims in the "War on Terror": Representations of ideological violence by Muslim versus non-Muslim perpetrators in Canadian National News Media. Religions (Basel, Switzerland ), 9(9), \#274, 1-26. https://doi.org/10.3390/re19090274

Kayaalp, D. (2014). Educational inclusion/exclusion of Turkish immigrant youth in Vancouver, Canada: a critical analysis. International Journal of Inclusive Education, 18(7), 655-668. https://doi.org/10.1080/13603116.2013.802031

Kayaalp, D. (2019). Towards culturally responsive education: A qualitative approach. European Journal Of Education, 2(2), 77-85. http://dx.doi.org/10.26417/ejed-2019.v2i2-65

Khalema, N., \& Wannas-Jones, J. (2003). Under the prism of suspicion: Minority voices in Canada postSeptember 11. Journal of Muslim Minority Affairs, 23(1), 25-39. https://doi.org/10.1080/13602000305928

Khawaja, N. (2016). Acculturation of the Muslims settled in the West. Journal of Muslim Mental Health, 10(1), 1-7. https://doi.org/10.3998/jmmh.10381607.0010.102

Kohli, R., Pizarro, M., \& Nevárez, A. (2017). The "new racism” of K-12 Schools: Centering critical research on racism. Review of Research in Education, 41(1), 182-202. https://doi.org/10.3102/0091732X16686949

Kugler, J. \& West-Burns, N. (2010). The CUS framework for culturally responsive and relevant pedagogy. Our Schools, Our Selves, 19(3).

Kumar, A. (2010). A foreigner carrying in the crook of his arm a tiny bomb. Duke University Press

Kumashiro, K. K. (2000). Toward a theory of anti-oppressive Education. Review of Educational Research, 70(1), 25-53. https://doi.org/10.2307/1170593

Kumashiro, K. K. (2001). "Posts" perspectives on anti-oppressive education in social studies, English, mathematics, and science Classrooms. Educational Researcher, 30(3), 3-12.

https://doi.org/10.3102/0013189X030003003 
Ladson-Billings, G. (1995a). But that's just good teaching! The case for culturally relevant pedagogy. Theory into Practice, 34(3), 159-165. https://doi.org/10.1080/00405849509543675

Ladson-Billings, G. (1995b). Toward a theory of culturally relevant pedagogy. American Educational Research Journal, 32(3), 465-491. https://doi.org/10.2307/1163320

Ladson-Billings, G. (1998). Just what is critical race theory and what's it doing in a nice field like education? International journal of qualitative studies in education, 11(1), 7-24. https://doi.org/10.1080/095183998236863

Ladson-Billings, G. (2014). Culturally relevant pedagogy 2.0: a.k.a. the remix. Harvard Educational Review, 84(1), 74-84. https://doi.org/10.17763/haer.84.1.p2rj131485484751

Lebowitz, J. (2016). Muslim American youth in the post 9/11 public education system. https://cedar.wwu.edu/cgi/viewcontent.cgi?article=1005\&context=fairhaven_acscapstone

Lee, C. D. (2017). An ecological framework for enacting culturally sustaining pedagogy. In. D. Paris \& Alim, H. S. (Eds.), Culturally sustaining pedagogies: Teaching and learning for justice in a changing world (pp. 261-273). Teachers College Press.

Lee, S. J., \& Walsh, D. (2012). Resistance and accommodation: Social justice education for immigrant youth in an era of high stakes testing. Encyclopaideia: Journal of Phenomenology and Education, 34, 1536.

Leeman, Y. \& Saharso, S. (2013). Coming of age in Dutch schools: Issues of schooling and identity. Education Inquiry (Co-Action Publishing), 4(1), 11-30. https://doi.org/10.3402/edui.v4i1.22060

Lund, D. E. (2006). Rocking the racism boat: school-based activists speak out on denial and avoidance. Race Ethnicity and Education, 9(2), 203-221. https://doi.org/10.1080/13613320600696813

Maged, S. (2014). Breaking the silence of exclusion: examining the complexities of teacher education for cultural diversity. Educational Research for Policy and Practice, 13(3), 181-197. https://doi.org/10.1007/s10671-013-9157-1

McDonough, S. \& Hoodfar, H. (2005). Muslims in Canada: From ethnic groups to religious community. In: P. Bramadat P \& D. Seljak (Eds.), Religion and ethnicity in Canada (pp. 133-153). University of Toronto Press.

McGee Banks, C., \& Banks, J. (1995). Equity pedagogy: An essential component of multicultural education. Theory into Practice, 34(3), 152-158. https://doi.org/10.1080/00405849509543674

McLaren, P. (1992). Critical literacy and postcolonial praxis: A Freirian Perspective. College Literature, 19/20(3/1), 7-27. https://digitalcommons.chapman.edu/education_articles/156/

McLaren, P. (2002). Critical pedagogy: A look at the major concepts. Routledge/Falmer Press.

Nelson, T. H., Slavit, D., Perkins, M., \& Hathorn, T. (2008). A culture of collaborative inquiry: Learning to develop and support professional learning communities. Teachers College Record, 110(6), 12691303.

Nieto, S. (2000). Placing equity front and center: Some thoughts on transforming teacher education for a new century. Journal of Teacher Education, 51(3), 180-187. https://doi.org/10.1177/0022487100051003004

Niyozov, S., \& Niyozov, S. (2010). Teachers and teaching Islam and Muslims in pluralistic societies: Claims, misunderstandings, and responses. Journal of International Migration and Integration, 11(1), 23-40. https://doi.org/10.1007/s12134-009-0123-y

Niyozov, S., \& Pluim, G. (2009). Teachers' perspectives on the education of Muslim students: A missing voice in Muslim education research. Curriculum Inquiry, 39(5), 637-677.

https://doi.org/10.1111/j.1467-873X.2009.00463.x 
North, C. (2008). What is all this talk about "social justice"? Mapping the terrain of education's latest catchphrase. Teachers College Record, 110(6), 1182-1206.

Ontario. Ministry of Education. (2009). Realizing the Promise of Diversity...: Ontario's Equity and Inclusive Education Strategy. Ministry of Education.

Ozturgut, O. (2011). Understanding multicultural education. Current Issues in Education, 14(2), 1-10. https://cie.asu.edu/ojs/index.php/cieatasu/article/download/732/225/0

Paris, D. (2011). "A friend who understand fully": notes on humanizing research in a multiethnic youth community. International Journal of Qualitative Studies in Education, 24(2), 137-149. https://doi.org/10.1080/09518398.2010.495091

Paris. D. (2012). Culturally sustaining pedagogy: A needed change in stance, terminology, and practice. Educational Researcher, 41(3), 93-97. https://doi.org/10.3102/0013189X12441244

Paris, D., \& Alim, H. (2017). Culturally sustaining pedagogies: teaching and learning for justice in a changing world. Teachers College Press.

Parker-Jenkins, M., Francia, G., \& Edling, S. (2017). Education for the other: policy and provision for Muslim children in the UK and Swedish education systems. Compare, 47(2), 257-270. https://doi.org/10.1080/03057925.2016.1168282

Peterson, E., Rubie-Davies, C., Osborne, D., \& Sibley, C. (2016). Teachers' explicit expectations and implicit prejudiced attitudes to educational achievement: Relations with student achievement and the ethnic achievement gap. Learning and Instruction, 42, 123-140.

https://doi.org/10.1016/j.learninstruc.2016.01.010

Poynting, S., \& Perry, B. (2007). Climates of hate: Media and state Inspired victimisation of Muslims in Canada and Australia since 9/11. Current Issues in Criminal Justice, 19(2), 151-171. https://doi.org/10.1080/10345329.2007.12036423

Pronin, E. (2006). Perception and misperception of bias in human judgment. Trends in Cognitive Sciences, 11(1), 37-43. https://doi.org/10.1016/j.tics.2006.11.001

Putnam, R. T., \& Borko, H. (2000). What do new views of knowledge and thinking have to say about research on teacher learning? Educational Researcher, 29(1), 4-15. https://doi.org/10.2307/1176586

Ready, D. D., \& Wright, D. L. (2011). Accuracy and inaccuracy in teachers' perceptions of young children's cognitive abilities: The role of child background and classroom context. American Educational Research Journal, 48(2), 335-360. https://doi.org/10.3102/0002831210374874

Rizvi, F., \& Lingard, B. (2006). Edward Said and the cultural politics of education. Discourse (Abingdon, England), 27(3), 293-308. https://doi.org/10.1080/01596300600838744

Roberts, P. (2015). Paulo Freire and utopian education. The Review of Education/pedagogy/cultural Studies, 37(5), 376-392. https://doi.org/10.1080/10714413.2015.1091256

Saeed, A. (2007). Media, racism and Islamophobia: The representation of Islam and Muslims in the media. Sociology Compass, 1(2), 443-462. https://doi.org/10.1111/j.1751-9020.2007.00039.x

Sahli, B., Tobias-Nahi, C., \& Abo-Zena, M. (2009). Authentic interactions: Eliminating the anonymity of otherness. In Y. Haddad, F. Senzai, \& J. Smith (Eds.), Educating the Muslims of America (pp. 231250). Oxford University Press.

Said, E. W. (2003a). Orientalism. Penguin. (Original work published 1978)

Said, E. (2003b). The Clash of Definitions. In E. Qureshi and M. A. Sells (Eds.), The new Crusades: Construction of the Muslim enemy (pp. 68-87). Columbia University Press.

Said, E., \& Viswanathan, G. (2001). Power, politics, and culture: interviews with Edward W. Said . Pantheon Books. 
Saleh, M. (2021). "We need a new story to guide us": Towards a curriculum of Rahma, Curriculum Inquiry, 51(2), 210-228. https://doi.org/10.1080/03626784.2020.1860642

Schmuck, D., Matthes, J., von Sikorski, C., Materne, N., \& Shah, E. (2018). Are unidentified terrorist suspects always Muslims? How terrorism news shape news consumers' automatic activation of Muslims as perpetrators. Religions (Basel, Switzerland ), 9(10), \#286, 1-16. https://doi.org/10.3390/re19100286

Sensoy, O., \& DiAngelo, R. (2014). Respect differences? Challenging the common guidelines in social justice education. Democracy \& Education, 22(2), 1-10.

Shultz, L. (2011). Engaging the multiple discourses of global citizenship education within a Canadian university: Deliberation, contestation, and social justice possibilities. In L. Shultz, A. A. Abdi, \& G. Richardson (Eds.), Global citizenship education in post-secondary institutions: Theories, practices, policies (pp. 13-24). Peter Lang.

Singh, J. (2016). The death of Islamophobia: The rise of Islamo-Racism. Race Files. www.racefiles.com/2016/02/23/the-death-of-islamophobia-the-rise-of-islamo-racism/

Sleeter, C., \& Stillman, J. (2005). Standardizing knowledge in a multicultural society. Curriculum Inquiry, 35(1), 27-46. https://doi.org/10.1111/j.1467-873X.2005.00314.X

Sirin, S., \& Balsano, A. (2007). Editors' Introduction: Pathways to identity and positive development among Muslim youth in the west. Applied Developmental Science, 11(3), 109-111. https://doi.org/10.1080/10888690701454534

Stewart, B. (2019, March 20). Police 'strongly believe' suspected Christchurch gunman planned to attack 3rd mosque. CBC News. https://www.cbc.ca/news/world/police-strongly-believe-suspectedchristchurch-gunman-planned-to-attack-3rd-mosque-1.5063704

Tatar, M., \& Horenczyk, G. (2003). Diversity-related burnout among teachers. Teaching and Teacher Education, 19, 397-408. https://doi.org/10.1016/S0742-051X(03)00024-6.

Timmermans, A., de Boer, H., \& van der Werf, M. (2016). An investigation of the relationship between teachers' expectations and teachers' perceptions of student attributes. Social Psychology of Education, 19(2), 217-240. https://doi.org/10.1007/s11218-015-9326-6

Toronto Police Services. (2016). Annual Hate/Bias Crime Statistical Report.

Toronto District School Board (TDSB). (2017). Islamic Heritage Month Resource Guide.

Truth and Reconciliation Commission of Canada. (2015). Truth and Reconciliation Commission of Canada: Calls to action. http://publications.gc.ca/collections/collection_2015/trc/IR4-7-2015-eng.pdf.

Tuck, E., \& Yang, K. W. (2012). Decolonization is not a metaphor. Decolonization: Indigeneity, education \& society, 1(1), 1-40. https://jps.library.utoronto.ca/index.php/des/article/view/18630/15554

Tuncel, G. (2017). Improving the Cultural Responsiveness of Prospective Social Studies Teachers: An Action Research. Educational Sciences: Theory and Practice, 17(4), 1317-1344.

van den Bergh, L., Denessen, E., Hornstra, L., Voeten, M., \& Holland, R. W. (2010). The implicit prejudiced attitudes of teachers: Relations to teacher expectations and the ethnic achievement gap. American Educational Research Journal, 47(2), 497-527. https://doi.org/10.3102/0002831209353594

van Kessel, C. (2020). Teaching the climate crisis: Existential considerations. Journal of Curriculum Studies Research, 2(1), 129-145. https://doi.org/10.46303/jcsr.02.01.8

van Kessel, C., \& Saleh, M. (2020). Fighting the plague: "Difficult" knowledge as sirens' song in teacher education. Journal of Curriculum Studies Research, 2(2), 1-20. https://doi.org/10.46303/jcsr.2020.7

Von Hlatky, S., \& Ibrahim, N. A. (2017). Violent extremism in Canada and abroad. https://www.queensu.ca/cidp/sites/webpublish.queensu.ca.cidpwww/files/files/Research/Policy\%20 Reports/CVE-Report_2017_E.pdf 
Waters, T. \& Leblanc, K. (2005) Refugees and education: mass public schooling without a nationstate, Comparative Education Review, 49, 129-147. https://doi.org/10.1086/428102

Weiler, K. (1991). Freire and a feminist pedagogy of difference. Harvard Educational Review, 61(4), 449474. https://doi.org/10.17763/haer.61.4.a102265j168rju84

Fillmore, L. (2000). Loss of family languages: Should educators be concerned? Theory into Practice, 39(4), 203-210. https://doi.org/10.1207/s15430421tip3904_3

Younis, T.\& Hassan G. (2019). Second-generation Western Muslims: A qualitative analysis of multiple social identities. Transcultural Psychiatry, 56(6):1155-1169. https://doi.org/10.1177/1363461518804554

Zhao, C. M., Kuh, G. D., \& Carini, R. M. (2005). A comparison of international student and American student engagement in effective educational practices. The Journal of Higher Education (Columbus), 76(2), 209-231. https://doi.org/10.1353/jhe.2005.0018

Zine, J. (2000). Redefining resistance: Towards an Islamic subculture in schools. Race Ethnicity and Education, 3(3), 293-316. https://doi.org/10.1080/713693042

Zine, J. (2001). Muslim Youth in Canadian Schools: Education and the Politics of Religious Identity. Anthropology \& Education Quarterly, 32(4), 399-423.

https://doi.org/10.1525/aeq.2001.32.4.399

Zine, J. (2002). Inclusive schooling in a plural society: Removing the margins. Education Canada, 42(3), 36-39. https://youthrex.com/wp-content/uploads/2019/02/EdCan-2002-v42-n3-Zine.pdf .

Zine, J. (2003). Dealing with September 12th: The challenge of anti-Islamophobia education. Orbit, 33(3), $39-41$.

Zine, J. (2006). Unveiled sentiments: Gendered Islamophobia and experiences of veiling among Muslim girls in a Canadian Islamic school. Equity \& Excellence in Education, 39, 239-252. https://www.doi.org/10.1080/10665680600788503

Zine, J. (2012). Anti-Islamophobia education as transformative pedagogy: Reflections from the educational front lines. AULA Intercultural. https://aulaintercultural.org/2012/10/17/anti-islamophobiaeducation-as-transformative-pedagogy-reflections-from-the-educational-front-lines/ 